\title{
Highly ACE2 Expression in Pancreas May Cause Pancreas Damage
}

\section{After SARS-CoV-2 Infection}

Furong Liu ${ }^{1,2}$, Xin Long ${ }^{1,2}$, Wenbin $\mathrm{Zou}^{3}$, Minghao Fang ${ }^{4}$, Wenjuan $\mathrm{Wu}^{5}$, Wei $\mathrm{Li}^{6}$, Bixiang Zhang ${ }^{1,2}$, Wanguang Zhang ${ }^{1,2}$, Xiaoping Chen ${ }^{1,2}$, Zhanguo Zhang ${ }^{1,2^{*}}$

\section{Author's Affiliation}

${ }^{1}$ Hepatic Surgery Center, Tongji Hospital, Tongji Medical College, Huazhong University of Science and Technology, Wuhan, Hubei 430030, China.

${ }^{2}$ Hubei Province for the Clinical Medicine Research Center of Hepatic Surgery, Wuhan, Hubei 430030, China.

${ }^{3}$ Department of Thoracic Surgery, Tongji Hospital, Tongji Medical College, Huazhong University of Science and Technology, Wuhan, Hubei 430030, China.

${ }^{4}$ Department of Critical Care Medicine, Tongji Hospital, Tongji Medical College, Huazhong University of Science and Technology, Wuhan, Hubei 430030, China.

${ }^{5}$ Department of Critical Care Medicine, Jin Yin-tan Hospital, Wuhan, Hubei 430022, China.

${ }^{6}$ Department of Obstetrics and Gynecology, Tongji Hospital, Tongji Medical College, Huazhong University of Science and Technology, Wuhan, Hubei 430030, China.

\section{*Corresponding Author}

Dr. Zhanguo Zhang

Hepatic Surgery Center, Tongji Hospital, Tongji Medical College, Huazhong University of Science and Technology, 1095 Jiefang Avenue, 430030 Wuhan, China.

Tel.: +86 27 83663400; fax: +86 2783662851 ; 
medRxiv preprint doi: https://doi.org/10.1101/2020.02.28.20029181; this version posted March 3, 2020. The copyright holder for this preprint (which was not certified by peer review) is the author/funder, who has granted medRxiv a license to display the preprint in perpetuity.

It is made available under a CC-BY-NC-ND 4.0 International license.

E-mail: zhanguo_tjh@hust.edu.cn 


\section{Abstract}

The ongoing outbreak of coronavirus disease 2019 (COVID-19) caused by severe acute respiratory syndrome coronavirus 2 (SARS-CoV-2) started in the end of 2019 in China has triggered a global public health crisis. Previous studies have shown that SARS-CoV-2 infects cells by binding angiotensin-converting enzyme 2 (ACE2), which is the same as SARS-CoV. The expression and distribution of ACE2 in the pancreas are unknown. At the same time, the injury of pancreas after SARS-CoV-2 infection has not been concerned. Here, we collected public datasets (bulk RNA-seq and single-cell RNA-seq) to indicate the expression and the distribution of ACE2 in pancreas (in both exocrine glands and islets). And further, clinical data including mild and severe patients with COVID-19 demonstrated there existed mild pancreatitis. In the 67 severe cases, 11 patients $(16.41 \%)$ showed elevated levels of both amylase and lipase, and 5 patients $(7.46 \%)$ showed imaging alterations. Only one patient $(1.85 \%)$ showed elevated levels of both amylase and lipase in 54 mild cases, without imaging changes. Our study revealed the phenomenon and possible cause of mild pancreatic injury in patients with COVID-19. This suggests that pancreatitis after SARS-CoV-2 infection should also be paid attention in clinical work. 
medRxiv preprint doi: https://doi.org/10.1101/2020.02.28.20029181; this version posted March 3, 2020. The copyright holder for this preprint (which was not certified by peer review) is the author/funder, who has granted medRxiv a license to display the preprint in perpetuity.

It is made available under a CC-BY-NC-ND 4.0 International license .

\section{Introduction}

Severe acute respiratory syndrome coronavirus 2 (SARS-CoV-2), a novel coronavirus that causes coronavirus disease 2019 (COVID-19) in humans, began to occur in Wuhan (China) in December 2019 and has the trend of spreading around the world[1, 2, 3]. By February 28, 2020, a total of 78962 people had been infected in China with 2791 (3.53\%) deaths, and 4838 people had been infected with $76(1.57 \%)$ deaths in other countries. It was confirmed by etiology that SARS-CoV-2 belonged to the novel coronavirus of the subgenus Sarbecovirus (Beta-CoV lineage B), and had 79.5\% similarity with SARS-CoV[4], which caused the global outbreak in 2003. Spike (S) protein, one of the main structural proteins of SARS-CoV-2, binds angiotensin-converting enzyme 2 (ACE2) protein of the host cell membrane to fuse into the cell for nucleic acid replication just similar to SARS-CoV[5]. Through a variety of bioinformatics and experimental verification, ACE2 is not only expressed in alveolar epithelial cells, but also in the heart, gastrointestinal tract, kidney, testis and other organs, which means that SARS-CoV-2 is likely to enter other tissues and organs through ACE2 binding, causing multiple organ damage[6, 7].

In recent studies, SARS-CoV-2 has been found to cause heart, kidney, liver injury and gastrointestinal symptoms in addition to lung lesions such as ARDS[6]. However, there is lacking attention in pancreatic injury, which may accelerate patients' progression. In our clinical observation, we also found that some patients showed signs of pancreatic injury, such as high levels of amylase and lipase in serum and urine. 
medRxiv preprint doi: https://doi.org/10.1101/2020.02.28.20029181; this version posted March 3, 2020. The copyright holder for this preprint (which was not certified by peer review) is the author/funder, who has granted medRxiv a license to display the preprint in perpetuity.

It is made available under a CC-BY-NC-ND 4.0 International license .

In this study, we used public datasets to explore the expression of ACE2 in the pancreas and various types of pancreatic cells. Combined with clinical data, we demonstrated the pancreatic injury in some patients with COVID-19, and explained for the first time that the pancreas was also a vulnerable organ after SARS-CoV-2 infection.

\section{Methods}

\section{Analysis of Public datasets}

We collected bulk RNA-seq data from GTEx (https://gtexportal.org), which contains normal tissue and organ sequencing data from multiple individuals. The data analysis was performed online. In addition, we collected data from single-cell RNA-seq (scRNA-seq) of the pancreas NCBI-GEO (GSE85241 (4 donors with 2,126 pancreatic cells), GSE84133 (4 donors with 8569 pancreatic cells)). The details of the donors are available in the previous report[8,9]. The scRNA-seq data processing process is as follows: Unique molecular identified (UMI) expression count matrix was obtained from the database, and Seurat object was created. Further quality control was performed, cells with high mitochondrial gene expression $>5 \%$ were filtered. The data was normalized and log-transformed with the method "LogNormalize" in NormalizeData function. Before we performed linear dimensional reduction, the data was scaling. And then principal component analysis (PCA) was performed to the data and determined the dimensionality. Finally, after clustering cells based on graph-based clustering approach, the non-linear dimensional reduction based on uniform manifold 
approximation and projection (UMAP) was performed the data to analyze and visualize the data. All of scRNA-seq data analysis was based on Seurat R package (version: 3.1.4) with the default parameters[10]. The annotation of cell types was completed based on the featured genes of each cluster and the cell markers of each type pancreas cell from CellMarker database[11] and previously report[8, 9].

\section{Collections of clinical data}

This is a retrospective and observational study from Wuhan Tongji hospital and Wuhan Jin Yin-tan hospital. We retrospectively analyzed patients diagnosed with COVID-19 from January 1, 2020 to February 15, 2020. The criteria for the diagnosis and severity of the patients were followed by the diagnosis and treatment scheme for COVID-19 (trial version 6) issued by National Health Commission of the People's Republic of China. We collect hospital admissions, laboratory tests, and imaging tests from clinical electronic medical records. In this study, we collected clinical information including age, gender, amylase and lipase in serum, and the imaging results including bedside ultrasound and abdominal CT. Mild COVID-19 patients with serum amylase and lipase in the normal range did not undergo the imaging evaluation of the pancreas, and their pancreas was assumed to be normal. Bedside ultrasound of the abdomen was all performed in critically ill patients, and CT was added if there were any abnormalities. 
medRxiv preprint doi: https://doi.org/10.1101/2020.02.28.20029181; this version posted March 3, 2020. The copyright holder for this preprint (which was not certified by peer review) is the author/funder, who has granted medRxiv a license to display the preprint in perpetuity.

It is made available under a CC-BY-NC-ND 4.0 International license .

\section{Results}

To determine the expression of ACE2 in normal pancreas of humans, we used the

GTEx database to explore ACE2 expression. We found ACE2 was expressed in many organs or tissues except most brain tissues (Fig. 1A), which suggests that these organs or tissues such as unreported ovary and thyroid might also be targets for SARS-CoV-2. For comparison, we compared ACE2 expression in lung and pancreatic tissues, since the lung is known to be the first target organ to be attacked by SARS-CoV-2. The mRNA level of ACE2 in pancreas was higher than that in lung (Fig. 1A, P $<0.001$, Wilcoxon signed rank test).

To investigate the distribution of ACE2 in the pancreas, we analyzed two scRNA-seq datasets. We identified different types of pancreatic cells, such as alpha cell, beta cell, acinar cell, ductal cell and several other types of cells (Fig. 1B, D). In GSE85241, ACE2 was expressed in 55 cells (2.59\%) among the total 2126 cells, most of which (81.82\%) were expressed in exocrine gland (duct cells and acinar cells), and a few (16.36\%) were expressed in pancreatic islets (alpha, beta, delta and PP cells) (Fig. 1C, Table 1). In GSE84133, 0.22\% (19/8550) cells expressed ACE2, with 52.63\% (10/19) expressed in duct cells, 5.26\% (1/19) expressed in acinar cells, 21.05\% (4/19) expressed in beta cells and 15.79\% (3/19) expressed in delta and PP cells (Fig. 1E, Table 1). Individual differences between donors from different sources may lead to differences in the analysis results of the two scRNA-seq datasets. These data still indicate that ACE2 is expressed in both the exocrine glands and islets, which may be the main potential part targeted by SARS-CoV-2 in the pancreas, resulting in 
pancreatic injury.

In our study cohort, among the indicators of pancreatitis we focused on, the main ones were the elevation of serum amylase and lipase. In mild cases, $1.85 \%(1 / 54)$ of patients showed elevated levels of both amylase and lipase, while in severe cases, the proportion of increased amylase was $17.91 \%(12 / 64)$ and the proportion of increased lipase was $16.41 \%(11 / 64)$ (Table 2). However, in the imaging evaluation, only 5 severe patients $(7.46 \%)$ showed changes in the pancreas, mainly focal enlargement of the pancreas or dilatation of the pancreatic duct, without acute necrosis (Fig. 2). These clinical data show that there exist mild pancreatic lesions in some patients with COVID-19, mainly in severe cases.

\section{Discussion}

SARS-CoV-2 infection is a very serious public health issue. It caused a nationwide spread in China, and now has the tendency to spread all over the world, causing a surge in infections and deaths[6]. So far, there is no specific drug for SARS-CoV-2, and challenges remain. Although there are asymptomatic infected people, who can also be the source of transmission[1, 12], in clinical practice, patients infected with SARS-CoV-2 mainly suffer from systemic symptoms like fever and fatigue, respiratory symptoms like cough and expectoration, digestive symptoms such as diarrhea[2, 13]. In some patients, especially critically ill cases, damage to other organs, such as the heart, kidneys, and liver, has also been found, which brings great inconvenience to manage patients $[2,14]$. As the receptor of SRAS-CoV-2, the 
medRxiv preprint doi: https://doi.org/10.1101/2020.02.28.20029181; this version posted March 3, 2020. The copyright holder for this preprint (which was not certified by peer review) is the author/funder, who has granted medRxiv a license to display the preprint in perpetuity.

It is made available under a CC-BY-NC-ND 4.0 International license .

expression of protein ACE2 in these organs may provide an approach for

SARS-CoV-2 infection[7], leading to tissue injuries. However, the injury of pancreas

has been ignored in clinic, since the symptoms of mild pancreatic injury are not

specific to other systemic lesions, such as fever, nausea, vomiting and abdominal

pain.

In this study, we focused on the expression of ACE2 in pancreas and the damage to the pancreas in a proportion of patients with SARS-CoV-2 infection. Although many

previous studies have been reported on the expression of ACE2 tissues and organs[15], including bulk RNA-seq and scRNA-seq data, this analysis in the pancreas is still lacking. Firstly, we found ACE2 was mostly expressed in the pancreas of normal people, and it was slightly higher in the pancreas than in the lungs, indicating that when SARS-CoV-2 appeared in the circulation, it might also combine with ACE2 in the pancreas to enter cells and cause pancreatic injury. Further, we performed scRNA-seq datasets of the pancreas to explore the localized expression of ACE2 in the pancreas. ACE2 is expressed in both exocrine glands and islets. At the same time, analysis results from scRNA-seq data were consistent with elevated levels of amylase and lipase in the plasma of our patients.

In our cases, about $1-2 \%$ of the non-severe patients with SARS-CoV-2 had pancreatic lesions, and about $17 \%$ of the severe patients suffered from pancreatic injuries, which was not previously noticed. Although their imaging alterations suggested that pancreatitis was not severe, the problem should not be ignored, especially in severe patients. In the clinic, the consequences of pancreatic injury can still be very serious, 
such as aggravating systemic inflammation, especially in the lungs and accelerating the occurrence of acute respiratory distress syndrome (ARDS)[16], and even developing into chronic pancreatitis without early intervention, which will have a serious impact on the health and quality of life of patients. On the other hand, Yang et al. reported that patients infected with SARS-CoV who had never used glucocorticoids suffered from hyperglycemia, which might be caused by SARS-CoV damaging the pancreatic islets through ACE2[16, 17]. Since SARS-CoV-2 has the same receptor as SARS-COV, whether this result will occur requires more attention. Therefore, increased attention should be paid to the pancreas in patients with SARS-CoV-2 infection, especially in severe cases.

In our study, there are still some limitations. There is no direct evidence that the slight damage to the pancreas was caused by SARS-COV-2 binding to ACE2 in the pancreas, and no studies have shown that nucleic acids of SARS-COV-2 have been detected in the pancreas. Due to the particularity of the location of the pancreas, this study could not be carried out. At present, the body anatomy has been conducted in China, and we hope to see this result in the future. At the same time, the systemic inflammatory response in severe COVID-19 patients might also cause mild damage to the pancreas. However, in the causes of pancreatitis, virus infection factors such as mumps, herpes simplex virus should not be ignored[18]. Our study provides a new idea and a possible mechanism. 


\section{Authors' contributions}

FRL, ZGZ conceived this study. ZGZ, BXZ, WGZ, XL, WBZ, MHF, WJW, WL, collected the clinical data. FRL and ZGZ analyzed the data. XPC provided the advices of this study. FRL and ZGZ wrote the manuscript. All authors read and approved the final manuscript.

\section{Funding}

This study was funded by the State Key Project on Infection Disease of China (No.

2018ZX10723204-003); the Chinese Ministry of Public Health for Key Clinical

Project (No. [2010] 493-51); National Natural Science Foundation of China

(81502530, 81874189 and 81874149).

\section{Availability of data and materials}

All data generated or analyzed during this study are included in the manuscript.

\section{Ethics approval and consent to participate}

This research was authorized by the Ethic Committee of Wuhan Tongji Hospital.

\section{Consent for publication}

All authors agree to submit for consideration for publication in the journal. 


\section{Competing interests}

The authors declare that they have no competing interests.

\section{References:}

1 Rothe C, Schunk M, Sothmann P, et al. Transmission of 2019-nCoV Infection from an Asymptomatic Contact in Germany. N Engl J Med 2020.

2 Chen N, Zhou M, Dong X, et al. Epidemiological and clinical characteristics of 99 cases of 2019 novel coronavirus pneumonia in Wuhan, China: a descriptive study. Lancet 2020;395:507-13.

3 Hoehl S, Berger A, Kortenbusch M, et al. Evidence of SARS-CoV-2 Infection in Returning Travelers from Wuhan, China. N Engl J Med 2020.

4 Zhou P, Yang XL, Wang XG, et al. A pneumonia outbreak associated with a new coronavirus of probable bat origin. Nature 2020.

$5 \mathrm{Xu} \mathrm{X}$, Chen $\mathrm{P}$, Wang J, et al. Evolution of the novel coronavirus from the ongoing Wuhan outbreak and modeling of its spike protein for risk of human transmission. Sci China Life Sci 2020.

$6 \mathrm{Xu}$ B, Kraemer M. Open access epidemiological data from the COVID-19 outbreak. Lancet Infect Dis 2020 .

7 Hamming I, Timens W, Bulthuis ML, et al. Tissue distribution of ACE2 protein, the functional receptor for SARS coronavirus. A first step in understanding SARS pathogenesis. J Pathol 2004;203:631-7.

8 Muraro MJ, Dharmadhikari G, Grun D, et al. A Single-Cell Transcriptome Atlas of the Human Pancreas. Cell Syst 2016;3:385-94.

9 Baron M, Veres A, Wolock SL, et al. A Single-Cell Transcriptomic Map of the Human and Mouse Pancreas Reveals Inter- and Intra-cell Population Structure. Cell Syst 2016;3:346-60.

10 Stuart T, Butler A, Hoffman P, et al. Comprehensive Integration of Single-Cell Data. Cell 2019;177:1888-902.

11 Zhang X, Lan Y, Xu J, et al. CellMarker: a manually curated resource of cell markers in human and mouse. Nucleic Acids Res 2019;47:D721-8.

12 Bai Y, Yao L, Wei T, et al. Presumed Asymptomatic Carrier Transmission of COVID-19. JAMA 2020 .

$13 \mathrm{Xu}$ XW, Wu XX, Jiang XG, et al. Clinical findings in a group of patients infected with the 2019 novel coronavirus (SARS-Cov-2) outside of Wuhan, China: retrospective case series. BMJ 2020;368:m606.

14 Yang X, Yu Y, Xu J, et al. Clinical course and outcomes of critically ill patients with SARS-CoV-2 pneumonia in Wuhan, China: a single-centered, retrospective, observational study. The Lancet Respiratory Medicine 2020.

$15 \mathrm{Xu} \mathrm{H}$, Zhong L, Deng J, et al. High expression of ACE2 receptor of 2019-nCoV on the epithelial cells of oral mucosa. Int J Oral Sci 2020;12:8. 
medRxiv preprint doi: https://doi.org/10.1101/2020.02.28.20029181; this version posted March 3, 2020. The copyright holder for this preprint (which was not certified by peer review) is the author/funder, who has granted medRxiv a license to display the preprint in perpetuity. It is made available under a CC-BY-NC-ND 4.0 International license.

16 Zhou MT, Chen CS, Chen BC, et al. Acute lung injury and ARDS in acute pancreatitis: mechanisms and potential intervention. World J Gastroenterol 2010;16:2094-9.

17 Yang JK, Feng Y, Yuan MY, et al. Plasma glucose levels and diabetes are independent predictors for mortality and morbidity in patients with SARS. Diabet Med 2006;23:623-8.

18 Parenti DM, Steinberg W, Kang P. Infectious causes of acute pancreatitis. Pancreas 1996;13:356-71. 
Figures:

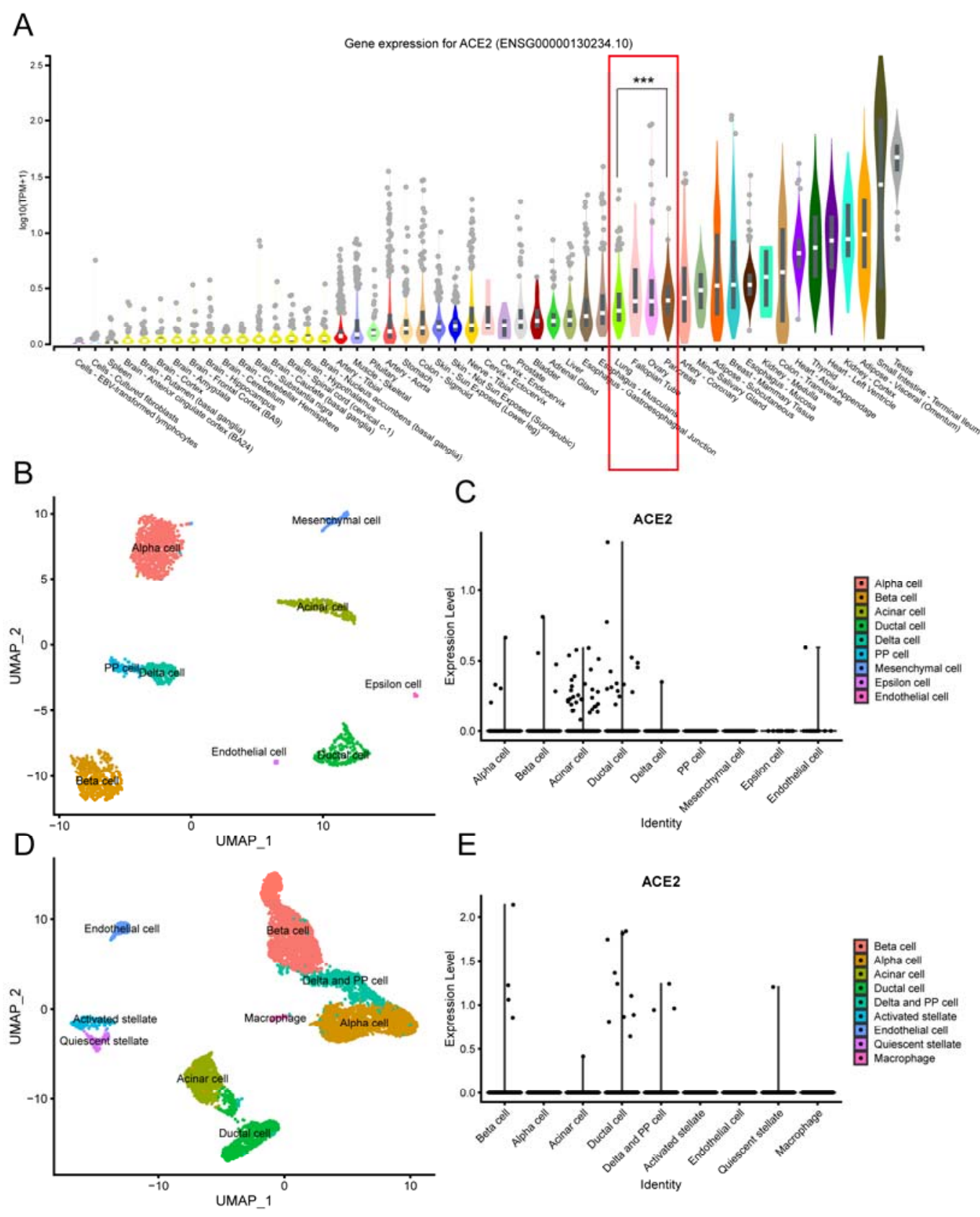

Figure 1. The expression and distribution of ACE2 in pancreas. (A) The mRNA level of ACE2 in multiple organs from GTEx samples. (B), (D) The visualization of pancreatic cell distribution by UMAP in GSE85241 and GSE84133. (C), (E) The expression of ACE2 in different pancreatic cell in GSE85241 and GSE84133. (***: P $<0.001)$ 
medRxiv preprint doi: https://doi.org/10.1101/2020.02.28.20029181; this version posted March 3, 2020. The copyright holder for this preprint (which was not certified by peer review) is the author/funder, who has granted medRxiv a license to display the preprint in perpetuity.

It is made available under a CC-BY-NC-ND 4.0 International license .

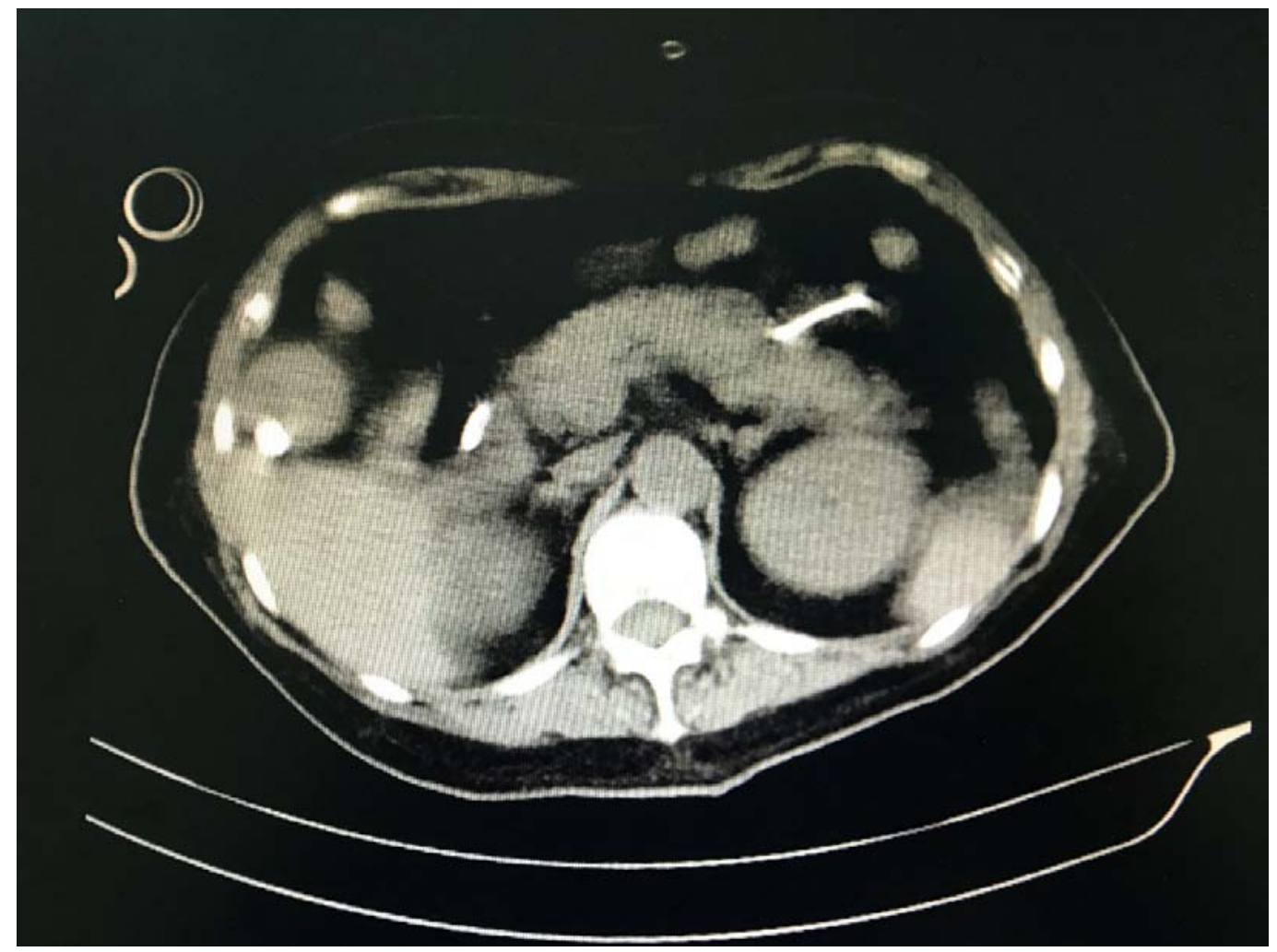

Figure 2. This CT scan shows an enlarged pancreas with dilated pancreatic ducts in a severe patient with COVID-19. 
medRxiv preprint doi: https://doi.org/10.1101/2020.02.28.20029181; this version posted March 3, 2020. The copyright holder for this preprint (which was not certified by peer review) is the author/funder, who has granted medRxiv a license to display the preprint in perpetuity. It is made available under a CC-BY-NC-ND 4.0 International license.

Table 1. The distribution of ACE2 in several type of pancreatic cell in two scRNA-seq datasets.

\begin{tabular}{ccc}
\hline & GSE85241 (N=55) & GSE84133(N=19) \\
\hline Exocrine gland & & \\
Duct cell & $14(25.45 \%)$ & $10(52.6 \%)$ \\
Acinar cell & $31(56.36 \%)$ & $1(5.26 \%)$ \\
Endothelial cell & $1(1.82 \%)$ & 0 \\
Pancreatic islet & & 0 \\
Alpha cell & $4(7.27 \%)$ & $4(21.05 \%)$ \\
Beta cell & $4(7.27 \%)$ & $3(15.79 \%)$ \\
PP and delta cell & $1(1.82 \%)$ & \\
\hline
\end{tabular}

Table 2. Characteristics of pancreatitis in patients with COVID-19.

\begin{tabular}{lccc}
\hline & All patients(N=121) & Non-severe(N=54) & Severe(N=67) \\
\hline $\begin{array}{l}\text { Age (Years) } \\
\text { Gender }\end{array}$ & $57.3(18-87)$ & $52.7(18-83)$ & $62.4(24-87)$ \\
$\quad$ Female & & & \\
$\quad$ Male & $46(38.02 \%)$ & $21(38.89 \%)$ & $25(37.31 \%)$ \\
Amylase/Lipase increased & $75(61.98 \%)$ & $33(61.11 \%)$ & $42(62.69 \%)$ \\
$\quad$ Amylase increased & $13(10.74 \%)$ & $1(1.85 \%)$ & $12(17.91 \%)$ \\
$\quad$ Lipase increased & $12(10.74 \%)$ & $1(1.85 \%)$ & $12(17.91 \%)$ \\
Imaging alteration & & $1(1.85 \%)$ & $11(16.41 \%)$ \\
$\quad$ A : Normal & $8(95.86 \%)$ & & \\
B: Enlargement or dilation & $5(4.13 \%)$ & $55(100 \%)$ & $62(92.54 \%)$ \\
$\quad$ C: Necrosis & 0 & 0 & $5(7.46 \%)$ \\
\hline
\end{tabular}

